\title{
Analisis Desain Pondasi Strauss Pile Pada Bangunan Rumah Sederhana Gunung Anyar Surabaya
}

\author{
Mila Kusuma Wardani ${ }^{1}$, Arintha Indah Dwi Syafiarti ${ }^{2}$, Faris Alqaisy ${ }^{3}$ \\ ${ }^{1,2,3}$ Program Studi Teknik Sipil, Fakultas Teknik Sipil dan Perencanaan, Institut Teknologi Adhi Tama Surabaya \\ Email: ${ }^{1}$ milakusuma@itats.ac.id, ${ }^{2}$ arintha@itats.ac.id
}

\begin{abstract}
Construction of a simple 2-story house located in Gunung Anyar, Surabaya with conditions based on an investigation of $19 \mathrm{~m}$ deep clay soft soil. The selection of the Strauss Pile Foundation based on the type of soil and building is simple. The calculation of the carrying capacity is calculated based on the Sondir data using the Meyerhoff method. The calculation of the settlement is carried out with an immediate and a consolidated. The calculation of the carrying capacity of the Strauss Pile is using the Meyerhoff method with variations in the diameter of the Strauss pile $20 \mathrm{~cm}, 30 \mathrm{~cm}$, $40 \mathrm{~cm}$ to a depth of $10 \mathrm{~m}$. The selected single pile selected at a depth of $7 \mathrm{~m}$ diameter $40 \mathrm{~cm}$ has an allowable carrying capacity value of 4.06 tons. From the results of the loading input on the residence using SAP 2000, the maximum load is 20.99 tons. Based on the single pile bearing capacity, the maximum load is 7 piles. Calculation of group piles obtained an efficiency value with 4D uniform pile spacing of $0.82 \%$ and a large decrease of $8.5 \mathrm{~cm}$. From the decrease obtained, it still fulfills the decrease in the decrease of $<15 \mathrm{~cm}$ based on the U.S.S.R
\end{abstract}

Keywords: clay, strauss pile, meyerhoff

\begin{abstract}
Abstrak
Pembangunan rumah tinggal sederhana 2 lantai yang berada di Gunung Anyar Surabaya dengan kondisi berdasarkan penyelidikan tanah terdapat tanah lunak sedalam $19 \mathrm{~m}$. Pemilihan pondasi Strauss Pile didasarkan pada jenis tanah dan tipe bangunan sederhana. Perhitungan daya dukung dihitung berdasarkan data tanah Sondir menggunakan Metode Meyerhoff. Perhitungan penurunan dilakukan dengan menghitung penurunan segera dan penurunan konsolidasi. Pada perhitungan daya dukung Strauss Pile dihitung menggunakan metode Meyerhoff dengan variasi diameter tiang strauss $20 \mathrm{~cm}, 30 \mathrm{~cm}, 40 \mathrm{~cm}$ yang dihitung sampai kedalaman $10 \mathrm{~m}$. Hasil perhitungan daya dukung tiang tunggal dipilih pada kedalaman $7 \mathrm{~m}$ diameter $40 \mathrm{~cm}$ nilai Qall sebesar 4,06 ton. Dari hasil input pembebanan pada rumah tinggal menggunakan SAP 2000 diperoleh beban maksimum sebesar 20,99 ton. Berdasarkan daya dukung tiang tunggal yang dipilih diperoleh pada beban maksimum jumlah tiang adalah 7 tiang. Perhitungan tiang kelompok diperoleh nilai efisiensi dengan jarak tiang seragam 4D sebesar $0,82 \%$ dan besar penurunan yang terjadi sebesar $8,5 \mathrm{~cm}$. Dari nilai penurunan yang diperoleh maka masih memenuhi dalam batasan penurunan ijin $<15 \mathrm{~cm}$ berdasarkan U.S.S.R.
\end{abstract}

Kata Kunci: tanah lempung, strauss pile, meyerhoff

\section{Pendahuluan}

Desain pondasi dapat dibedakan menjadi pondasi dangkal dan pondasi dalam, jenis tanah adalah pertimbangan utama dalam pemilihan fondasi. Kondisi tanah dengan kekuatan geser rendah membutuhkan pondasi yang kuat [1]. Secara umum kondisi tanah yang ada di Surabaya adalah tanah lunak dengan ketebalan 6-21 m [2]. Kondisi tanah dasar dapat diperoleh dari salah satu penyelidikan tanah di lapangan yaitu Sondir. Pengujian sondir merupakan salah satu jenis penyelidikan tanah dengan kesulitasn yang cukup rendah serta lebih akurat dibandingkan dengan pengujian lapangan lain [3]

Pondasi dalam ketentuan desain adalah suatu pondasi yang digunakan untuk pertimbangan pada kondisi tanah lunak yang cukup dalam. Teknik dalam pondasi dalam dapat disebut sebagai tiang pancang atau tiang bor, dimana kedua jenis tiang didasarkan pada metode pelaksanaan. Pondasi tiang pancang biasanya dilakukan dengan cara memukul tiang masuk dalam tanah, dimana gaya yang dapat ditahan termasuk gaya angkat dan daya lateral. Pondasi tiang bor menggunakan teknik pengeboran dengan membuat lubang dengan isi beton dan tulangan, saat ini teknik pengeboran juga mengikuti 
perkembangan [4]. Penggunaan pondasidalam juga dapat digunakan bila tanah lunak yang ada di lokasi tidak terlalu dalam. Pada pertimbangan desain suatu pondasi juga penting untuk memperhitungkan beban bekerja. Salah satu jenis sistem pondasiyang dapat dilakukan adalah dengan cara sistem pondasi strauss. Penggunaan pondasi strauss pile digunakan pada beban seperti rumah tinggal sederhana dengan bentang kolom $3-4 \mathrm{~m}$ [5]. Desain lain dapat juga diterapkan pembangunan gedung mini dengan beban 69,42 ton pada kedalaman tanah lunak $6 \mathrm{~m}$ [6].

Kekuatan pondasi direncanakan dan diperhitungkan dengan analisis yang baik agar dapat menjamin kestabilan bangunan sesuai beban bekerja [7]. Desain pondasi harus memenuhi kaidah daya dukung material dan tanah dasar serta besarnya penurunan. Perhitungan daya dukung pondasimenggunakan data sondir dapat dilakukan dengan cara Direct method, dimana dihitung langsung dari data pada ujung dan lekatan sondir [8]. Perhitungan kapasitas daya dukung pondasi menggunakan metode statis lebih baik dipilih yang paling mendekati kondisi lapangan. Dari beberapa metode dijumpai metode Meyerhoff memiliki nilai daya dukung paling dekat dengan kondisi lapangan yaitu $90.74 \%$ [9]. Metode Meyerhoff memiliki persamaan daya dukung yang dapat diaplikasikan baik pada tanah lempung atau tanah pasir [10].

Pengembangan pembangunan rumah tinggal 2 lantai di Surabaya dilakukan dibeberapa daerah salah satunya adalah di Gunung Anyar. Ukuran dari bangunan yang akan dikembangkan adalah tipe rumah tinggal dengan tipe 204/246. Data tanah yang diperoleh adalah data tanah sondir dengan kedalaman $19 \mathrm{~m}$. Nilai qc pada kedalaman $0-18 \mathrm{~m}$ termasuk dalam konsistensi lunak dengan nilai qc $=10-20 \mathrm{~kg} / \mathrm{cm}^{2}$, pada kedalaman akhir $19 \mathrm{~m}$ nilai qc $=250 \mathrm{~kg} / \mathrm{cm}^{2}$ adalah tanah pasir.

Studi ini digunakan untuk mengetahui daya dukung dan penurunan dengan desain strauss pile pada bangunan rumah sederhana. Analisis perbandingan diameter dari strauss pile yang digunakan pada pembahasan ini adalah diameter $20 \mathrm{~cm}, 30 \mathrm{~cm}$, dan $40 \mathrm{~cm}$. Pada masing - masing desain tersebut kemudian dibandingkan nilai daya dukung mendekati beban bekerja. Dari perbandingan daya dukung yang memenuhi tersebut dapat dihitung besar penurunan yang terjadi. Sehingga besarnya daya dukung dan penurunan pada tanah lunak diperoleh aman dan konstruksi rumah mampu berdiri dengan baik.

\section{Metode} berikut:

Metode yang digunakan dalam analisis perbandingan daya dukung strauss pile adalah sebagai

1. Analisis parameter data tanah lokasi pembangunan rumah tinggal sederhana yang digunakan dalam perhitungan daya dukung dan penurunan. Data tanah yang diperoleh dianalisis untuk keperluan perhitungan daya dukung dan penurunan.

2. Menghitung kapasitas daya dukung masing - masing diameter yaitu $20 \mathrm{~cm}, 30 \mathrm{~cm}$, dan 40 $\mathrm{cm}$. Perhitungan dilakukan dengan metode Meyerhoff pada tiap m kedalaman sampai akhir penyelidikan tanah.

3. Menentukan kedalaman pondasi strauss pile kemudian efisiensi, distribusi beban, lalu menghitung besarnya daya dukung kelompok. Penentuan kedalaman tanah dilakukan dengan pertimbangan beban maksimum, kemudian pada titik pembebnan lain juga dihitung besar jumlah tiang.

4. Menghitung besarnya kapasitas bahan dari pondasiyang kemudian dibandingkan dengan kapasitas daya dukung kelompok dari pondasi. Daya dukung pondasi kelompok pada setiap titik diambil yang maksimum untuk dianalisis pada perbandingan kebutuhan tiang

5. Memghitung besarnya penurunan dan membandingkan dengan batasan penurunan yang terjadi. Penurunan yang dihitung adalah penurunan segera ditambah dengan konsolidasi.

\section{Hasil dan Pembahasan}

\section{Analisis Data Tanah}

Data tanah yang diperoleh di Lokasi adalah data Sondir, NSPT, dan Laboratorium dengan titik penyelidikan sedalam $19 \mathrm{~m}$. Dari data tersebut diperoleh kondisi tanah yang didominasi tanah lempung pada kedalaman 1-18 m dengan nilai qc berkisar antara qc $2-20 \mathrm{~kg} / \mathrm{cm}^{2}$ dengan nilai fr $1,68 \%-5 \%$. 
Pada data laboratorium parameter yang diperoleh berupa nilai $\mathrm{Gs}, \mathrm{e}, \mathrm{Wc}, \phi, \mathrm{C}, \mathrm{Cu}, \gamma \mathrm{t}, \mathrm{Cc}$ dengan pengujian laboratorium dilakukan pada kedalaman $6 \mathrm{~m}, 12 \mathrm{~m}, 18 \mathrm{~m}, 24 \mathrm{~m}$, dan $30 \mathrm{~m}$.

Korelasi data dilakukan pada parameter daya dukung yaitu untuk memperoleh nilai $\mathrm{Cu}$ dengan menggunakan persamaan berdasarkan rumus Bowles [11]. Pada parameter penurunan kedalaman nilai $\gamma \mathrm{t}$ dan $\mathrm{e} 0$ diperoleh dari persamaan interpolasi. Pada parameter daya dukung korelasi dilakukan untuk memperoleh nilai $\mathrm{Cu}$ yang digunakan referensi perhitungan berdasarkan rumus Bowles [11] yaitu 0,6.N. Tabel 1 adalah data rekapitulasi dari data tanah yang digunakan dalam desain.

Tabel 1 Hasil Analisis Data Tanah Dasar

\begin{tabular}{cccccccc}
\hline $\begin{array}{c}\text { kedalaman } \\
(\mathrm{m})\end{array}$ & $\mathrm{qc}\left(\mathrm{kg} / \mathrm{cm}^{2}\right)$ & $\mathrm{NSPT}$ & $\gamma \mathrm{t}\left(\mathrm{t} / \mathrm{m}^{2}\right)$ & $\mathrm{eo}$ & $\mathrm{Cc}$ & $\mathrm{Cu}$ & $\mathrm{Po}^{\prime}\left(\mathrm{t} / \mathrm{m}^{2}\right)$ \\
\hline 1 & 8 & $\mathrm{NA}$ & $\mathrm{NA}$ & $\mathrm{NA}$ & $\mathrm{NA}$ & $\mathrm{NA}$ & $\mathrm{NA}$ \\
2 & 2 & 1 & 1.689 & 1.427 & 0.347 & 0.6 & 0.345 \\
3 & 2 & 1.5 & 1.683 & 1.422 & 0.346 & 0.9 & 1.031 \\
4 & 10 & 2 & 1.677 & 1.377 & 0.332 & 1.2 & 1.711 \\
5 & 9 & 1 & 1.689 & 1.427 & 0.347 & 0.6 & 2.934 \\
6 & 5 & 0 & 1.649 & 1.534 & 0.379 & 0.5 & 3.063 \\
7 & 8 & 0 & 1.649 & 1.534 & 0.379 & 0.5 & 3.712 \\
8 & 9 & 0 & 1.649 & 1.534 & 0.379 & 0.5 & 4.361 \\
9 & 9 & 0 & 1.649 & 1.427 & 0.379 & 0.5 & 5.010 \\
10 & 13 & 1 & 1.689 & 1.427 & 0.347 & 0.6 & 5.679 \\
11 & 18 & 1 & 1.689 & 1.427 & 0.347 & 0.6 & 6.368 \\
12 & 20 & 1 & 1.689 & 1.427 & 0.347 & 0.6 & 7.057 \\
13 & 12 & 2 & 1.677 & 1.377 & 0.332 & 1.2 & 7.740 \\
14 & 13 & 3 & 1.665 & 1.328 & 0.317 & 1.5 & 8.411 \\
15 & 10 & 3 & 1.665 & 1.328 & 0.317 & 1.5 & 9.076 \\
16 & 10 & 3 & 1.665 & 1.328 & 0.317 & 1.5 & 9.741 \\
17 & 10 & 3 & 1.665 & 1.328 & 0.317 & 1.5 & 10.406 \\
18 & 12 & 3 & 1.665 & 1.328 & 0.317 & 1.5 & 11.071 \\
19 & 250 & 40 & 1.781 & 1.315 & 0.314 & 6 & 11.744 \\
\hline
\end{tabular}

\section{Analisis Pembebanan}

Pemodelan pada struktur atas menggunakan bantuan software SAP2000 dengan parameter yang digunakan pada pemodelan struktur atas pada Gambar 1. Beban yang diperhitungkan pada perhitungan adalah beban mati dan beban hidup dengan kombinasi pembebanan sesuai SNI 1726 - 2012. Kombinasi pembebanan yang digunakan dalam desain adalah $1.0 \mathrm{D}+1.0 \mathrm{~L}$. Kombinasi pembebanan yang digunakan didapatkan nilai gaya-gaya dalam dengan nilai terbesar yaitu Pult, Mx, My, pada joint reaction yang akan digunakan untuk desain pondasi tiang strauss. Paksial maksimum yaitu pada titik 16 sebesar 20,99 ton. Dari besarnya Paksial digunakan sebagai perhitungan daya dukung tiang tunggal, tiang kelompok dan besarnya penurunan. 


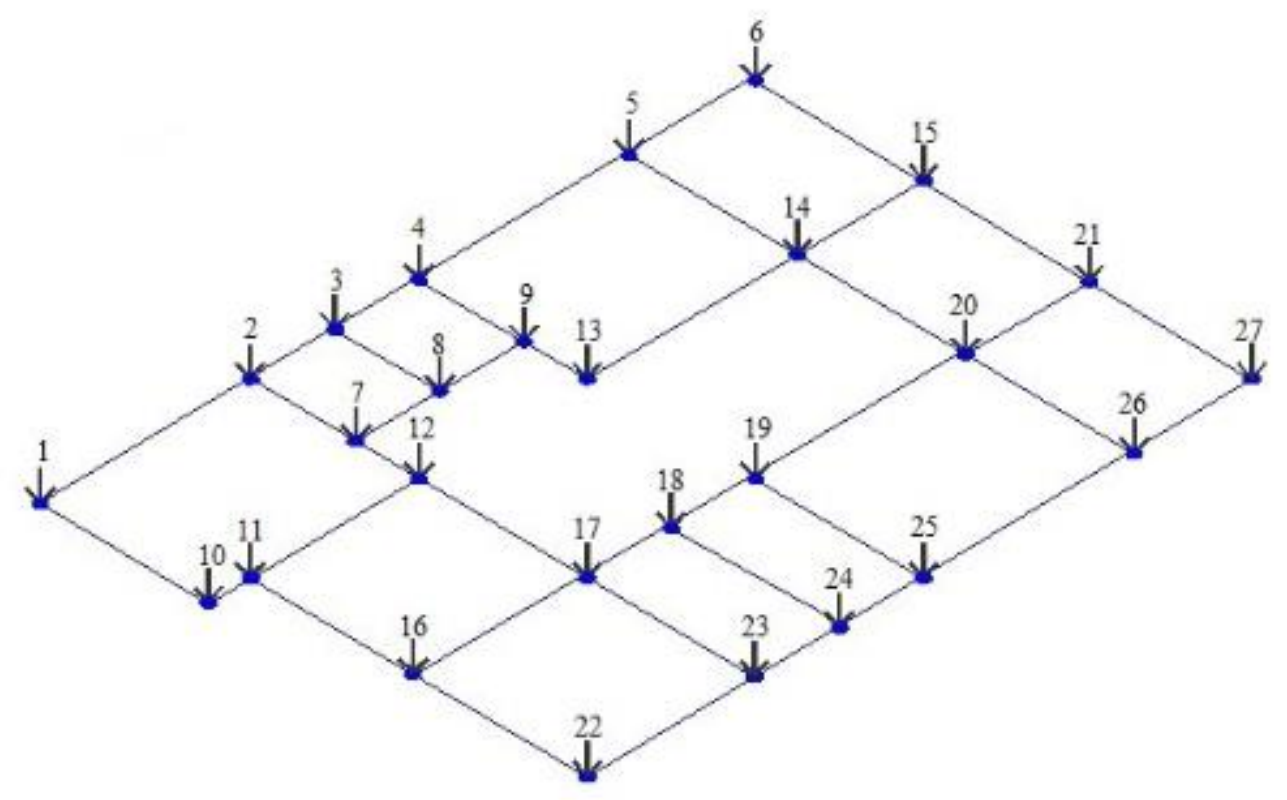

Gambar 1. Denah rumah dalam analisis beban

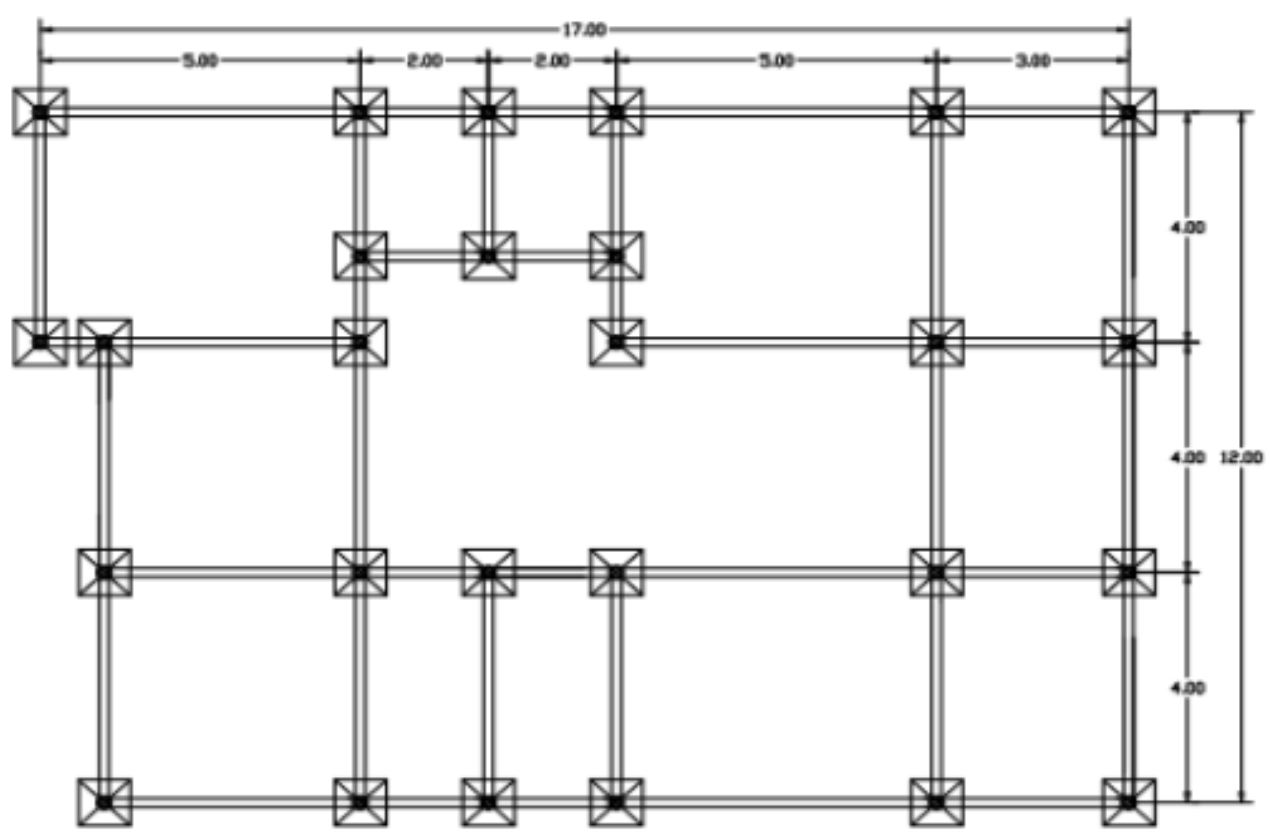

Gambar 2. Denah titik perletakan

\section{Analisis Daya Dukung Pondasi}

Pada perhitungan daya dukung metode Meyerhoff memiliki nilai faktor adhesi $(\alpha)=1$ berdasarkan jenis tanah untuk lempung terkonsolidasi normal dan 0,5 lempung terkonsolidasi berlebihan. Faktor adhesi yang digunakan dalam perhitungan adalah $(\alpha)=1$ dengan asumsi bahwa tanah 
lempung terkonsolidasi normal. Daya dukung tiang diambil dari nilai qc 4d di atas sampai $1 \mathrm{~d}$ di bawah ujung tiang. Tahanan selimut tiang dihitung dengan menghitung keliling sepanjang tiang tertanam. Hasil perhitungan daya dukung pada masing - masing diameter pondasidiberikan pada Tabel 2 .

Tabel 2 Perhitungan Daya Dukung Satu Tiang Pondasi

\begin{tabular}{cccc}
$\begin{array}{c}\text { kedalaman } \\
(\mathrm{m})\end{array}$ & \multicolumn{3}{c}{ Daya dukung ijn (Qallow $\left.\mathrm{t} / \mathrm{m}^{2}\right)$} \\
\hline 1 & 0.41 & 0.92 & 1.72 \\
2 & 0.8 & 0.77 & 1.27 \\
3 & 1.05 & 1.8 & 2.93 \\
4 & 2.08 & 3.63 & 5.6 \\
5 & 1.73 & 3.22 & 4.73 \\
6 & 1.21 & 2.28 & 3.6 \\
7 & 1.4 & 2.59 & 4.06 \\
8 & 1.75 & 3.11 & 4.41 \\
9 & 1.84 & 3.35 & 5.74 \\
10 & 2.64 & 4.76 & 7.34 \\
\hline
\end{tabular}

Tabel 3 Perbandingan perubahan daya dukung ijin

\begin{tabular}{|c|c|c|c|c|c|c|c|c|c|}
\hline \multirow{2}{*}{ kedalaman } & \multicolumn{9}{|c|}{ Persentase perubahan Daya dukung ijin (Qallow $\mathrm{t} / \mathrm{m}^{2}$ ) } \\
\hline & & & & & Meyerhoff & & & & \\
\hline$(\mathrm{m})$ & $\begin{array}{c}\mathrm{D}= \\
0,2 \mathrm{~m}\end{array}$ & Persentase $(\%)$ & $\begin{array}{c}\text { Rata- } \\
\text { rata }\end{array}$ & $\begin{array}{c}\mathrm{D}= \\
0,3 \mathrm{~m}\end{array}$ & Persentase $(\%)$ & $\begin{array}{c}\text { Rata- } \\
\text { rata }\end{array}$ & $\begin{array}{c}\mathrm{D}= \\
0,4 \mathrm{~m}\end{array}$ & Persentase $(\%)$ & $\begin{array}{c}\text { Rata- } \\
\text { rata }\end{array}$ \\
\hline 1 & 0.41 & - & & 0.92 & - & & 1.72 & - & \\
\hline 2 & 0.80 & 95.12 & 63.19 & 0.77 & 16.30 & 75.04 & 1.27 & 26.16 & 78.44 \\
\hline 3 & 1.05 & 31.25 & & 1.80 & 133.77 & & 2.93 & 130.71 & \\
\hline 4 & 2.08 & 98.10 & 48.72 & 3.63 & 101.67 & 82.24 & 5.62 & 91.81 & 79.45 \\
\hline 5 & 1.73 & 16.83 & & 3.22 & 11.29 & & 4.73 & 15.84 & \\
\hline 6 & 1.21 & 30.06 & 20.86 & 2.28 & 29.19 & 18.03 & 3.60 & 23.89 & 17.50 \\
\hline 7 & 1.40 & 15.70 & & 2.59 & 13.60 & & 4.06 & 12.78 & \\
\hline 8 & 1.75 & 25.00 & & 3.11 & 20.08 & & 4.41 & 8.62 & \\
\hline 9 & 1.84 & 5.14 & & 3.35 & 7.72 & & 5.74 & 30.16 & \\
\hline 10 & 2.64 & 43.48 & 22.33 & 4.76 & 42.09 & 20.87 & 7.34 & 27.87 & 19.86 \\
\hline
\end{tabular}

Dari hasil analisis perbandingan perubahan daya dukung ijin yang dihitung prosentase kenaikan dan rata - rata dengan penambahan kedalaman. Desain pondasi strauss pile ditentukan dengan diameter $0.4 \mathrm{~m}$ dengan kedalaman $7 \mathrm{~m}$ dengan nilai daya dukung 1 tiang adalah $4.06 \mathrm{t} / \mathrm{m}^{2}$. Hal ini ditentukan dari kenaikan daya dukung ijin rata - rata yaitu dari $17.50 \%$ ke $19.86 \%$.

\section{Penentuan Jumlah Tiang, Efisiensi dan Distribusi Tiang}

Pada perhitungan jumlah tiang dilakukan semua titik pembebanan sesuai dengan Gambar 2. Berdasarkan jumlah tiang kemudian dihitung nilai Efisiensi dengan Converse-Labarre Formula, syarat yang harus dipenuhi adalah berdasarkan Canadian National Building Code dalam [12] bahwa Eg > 80 $\%$ dengan jarak 2,5D sampai 4D. Hasil perhitungan direkapitulasi pada Tabel 4. 
Tabel 4 Hasil Perhitungan Daya Dukung Kelompok Strauss Pile

\begin{tabular}{|c|c|c|c|c|c|c|}
\hline $\begin{array}{l}\text { Kode Titik } \\
\text { Pembebanan }\end{array}$ & $\begin{array}{c}\text { P aksial } \\
\text { (ton) }\end{array}$ & $\begin{array}{c}\text { Qall } \\
\text { (kedalaman } 7 \\
\text { m) }\end{array}$ & Jumlah Tiang & $\mathrm{Eg}_{\mathrm{g}}$ & $\begin{array}{c}\mathrm{Qg}_{\mathrm{g}} \\
\text { (ton) }\end{array}$ & Keterangan \\
\hline 1 & 5.73 & 4.06 & 2 & 0.92 & 7.49 & oke \\
\hline 2 & 8.05 & 4.06 & 3 & 0.84 & 10.28 & oke \\
\hline 3 & 1.38 & 4.06 & 2 & 0.92 & 7.49 & oke \\
\hline 4 & 8.02 & 4.06 & 3 & 0.84 & 10.28 & oke \\
\hline 5 & 9.25 & 4.06 & 3 & 0.84 & 10.28 & oke \\
\hline 6 & 3.50 & 4.06 & 2 & 0.92 & 7.49 & oke \\
\hline 7 & 7.21 & 4.06 & 2 & 0.92 & 7.49 & oke \\
\hline 8 & 3.78 & 4.06 & 2 & 0.92 & 7.49 & oke \\
\hline 9 & 4.88 & 4.06 & 2 & 0.92 & 7.49 & oke \\
\hline 10 & 7.02 & 4.06 & 2 & 0.92 & 7.49 & oke \\
\hline 11 & 8.42 & 4.06 & 3 & 0.84 & 10.28 & oke \\
\hline 12 & 9.02 & 4.06 & 3 & 0.84 & 10.28 & oke \\
\hline 13 & 11.73 & 4.06 & 4 & 0.84 & 13.71 & oke \\
\hline 14 & 14.76 & 4.06 & 5 & 0.84 & 17.13 & oke \\
\hline 15 & 7.05 & 4.06 & 2 & 0.92 & 7.49 & oke \\
\hline 16 & 20.99 & 4.06 & 7 & 0.82 & 23.25 & oke \\
\hline 17 & 12.15 & 4.06 & 4 & 0.84 & 13.71 & oke \\
\hline 18 & 3.99 & 4.06 & 2 & 0.92 & 7.49 & oke \\
\hline 19 & 17.37 & 4.06 & 6 & 0.82 & 19.93 & oke \\
\hline 20 & 14.08 & 4.06 & 5 & 0.84 & 17.13 & oke \\
\hline 21 & 7.26 & 4.06 & 3 & 0.92 & 11.23 & oke \\
\hline 22 & 10.42 & 4.06 & 3 & 0.84 & 10.28 & oke \\
\hline 23 & 4.76 & 4.06 & 2 & 0.92 & 7.49 & oke \\
\hline 24 & 2.52 & 4.06 & 2 & 0.92 & 7.49 & oke \\
\hline 25 & 10.16 & 4.06 & 3 & 0.84 & 10.28 & oke \\
\hline 26 & 8.68 & 4.06 & 3 & 0.84 & 10.28 & oke \\
\hline 27 & 3.74 & 4.06 & 2 & 0.92 & 7.49 & oke \\
\hline
\end{tabular}

\section{Kontrol Daya Dukung Tiang Kelompok Terhadap Beban dan Mutu Bahan}

Kontrol kekuatan bahan tiang strauss menggunakan mutu fc' $250 \mathrm{Mpa}$, tujuan dilakukan analisis adalah untuk dilakukan untuk mengetahui kekuatan tiang kelompok dalam menahan beban aksial. kontrol mutu bahan digunakan untuk mengetahui bahan mengalami keretakan atau aman sesuai dengan perencanaan. Dari hasil perhitungan diperoleh mutu bahan tiang strauss terhadap kekuatan tanah adalah 103,62 ton $>23,25$ ton. Sehingga dari hasil tersebut dinyatakan bahwa kekuatan bahan tiang memenuhi terhadap daya dukung tiang dalam kelompok.

\section{Perhitungan Penurunan Pondasi Strauss}

Perhitungan penurunan tiang strauss dalam kelompok tiang dengan kedalaman tiang tertanam sedalam $7 \mathrm{~m}$ pada lapisan tanah lempung. Penurunan yang dihitung adalah penurunan segera dan penurunan konsolidasi. Pada perhitungan penurunan segera dibutuhkan besarnya angka modulus elastisitas (E) berdasarkan [13]. Parameter rasio poisson ( $\mu$ ) dengan kondisi 2 tiang strauss menggunakan Grafik menurut Janbu et al 1956. data yang dibutuhkan dalam menghitung penurunan 
segera lainnya antara lain nilai lebar (B) dan panjang (L) yang diperoleh dari dimensi pile cap dan nilai D merupakan $2 / 3$ kedalaman tiang yang dipilih dalam perencanaan, dengan nilai kedalaman tiang $(\mathrm{H})$ dihitung per meter. Tabel 5 menunjukkan besarnya paramter yang digunakan dalam perhitungan besar penurunan. Penurunan konsolidasi menggunakan parameter nilai e, Cc, dan po' pada Tabel 1. Ilustrasi perhitungan penurunan diberikan pada Gambar 3 .

Tabel 5 Parameter Penurunan Segera

\begin{tabular}{|c|c|c|c|c|c|c|c|c|}
\hline jumlah tiang & $\begin{array}{c}\mathbf{B} \\
(\mathbf{m}) \\
\end{array}$ & $\begin{array}{c}\mathbf{L} \\
(\mathbf{m})\end{array}$ & $\begin{array}{c}\mathbf{H} \\
(\mathbf{m}) \\
\end{array}$ & $\begin{array}{r}\mathrm{D}=\mathbf{L} \\
(\mathrm{m})\end{array}$ & $\begin{array}{r}\mathbf{H} / \mathbf{B} \\
(\mathrm{m}) \\
\end{array}$ & $\begin{array}{r}\mathrm{D} / \mathrm{B} \\
(\mathrm{m}) \\
\end{array}$ & $\mu 1$ & $\mu 0$ \\
\hline 2 & 4.1 & 4.7 & 1 & 4.67 & 0.24 & 1.14 & 1.70 & 0.730 \\
\hline 3 & 5.1 & 5.95 & 1 & 4.67 & 0.20 & 0.92 & 1.50 & 0.750 \\
\hline 4 & 5.7 & 5.7 & 1 & 4.67 & 0.18 & 0.82 & 1.20 & 0.780 \\
\hline 5 & 6.9 & 5.7 & 1 & 4.67 & 0.14 & 0.68 & 0.90 & 0.820 \\
\hline 6 & 5.7 & 7.3 & 1 & 4.67 & 0.18 & 0.82 & 1.20 & 0.780 \\
\hline 7 & 6.9 & 6.5 & 1 & 4.67 & 0.14 & 0.68 & 0.90 & 0.820 \\
\hline
\end{tabular}

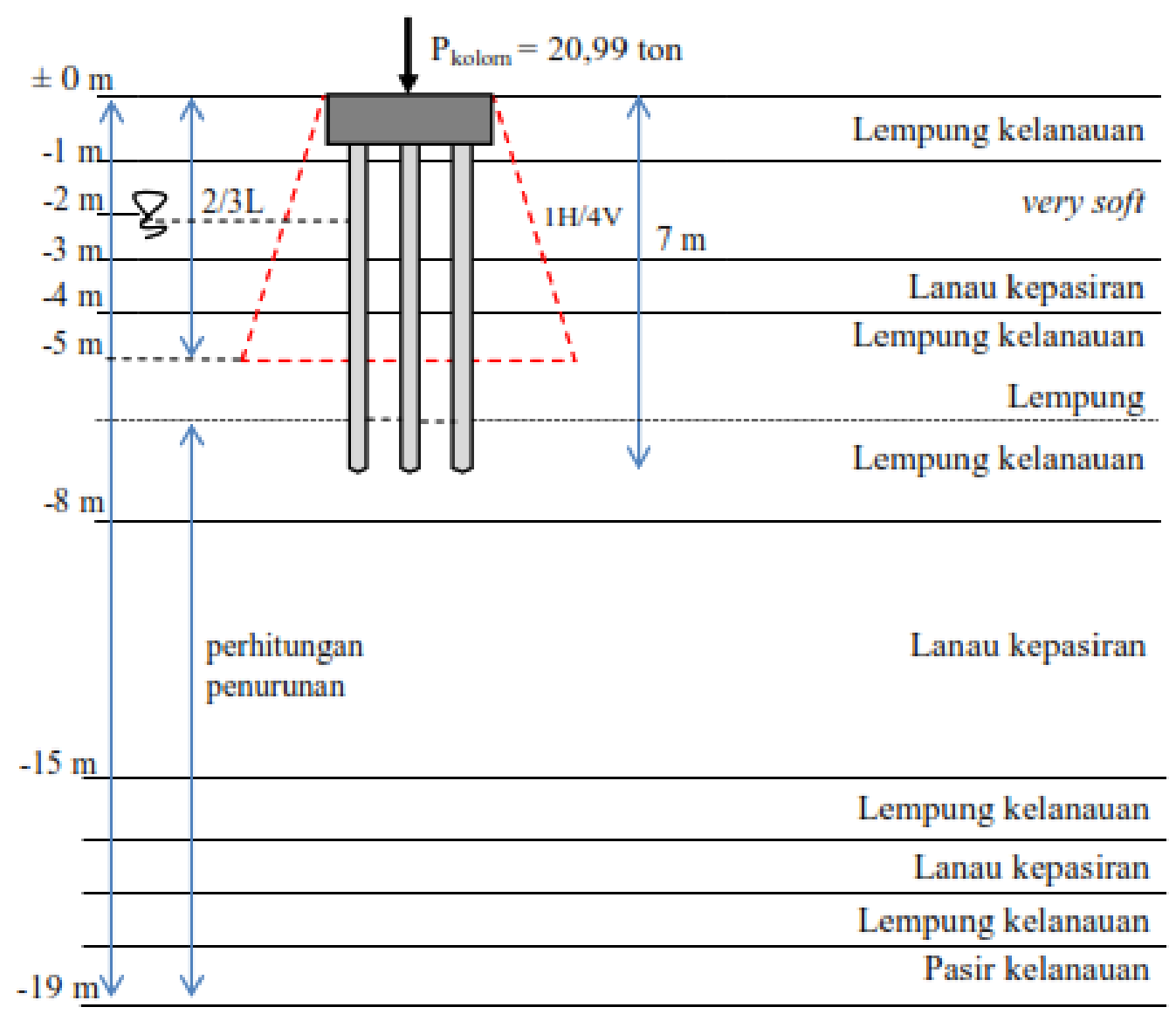

Gambar 3. Ilustrasi hitungan penurunan tiang kelompok

Batasan penurunan ijin berdasarkan 1955 U.S.S.R. Building Code [14] harus memenuhi penurunan ijin yaitu sebesar $15 \mathrm{~cm}$. Dari hasil perhitungan nilai penurunan yang telah diperoleh dapat dilihat bahwa penurunan terbesar ada pada titik pembebanan nomor 16 dengan penurunan segera sebesar 0,031 $\mathrm{m}$ dan penurunan konsolidasi sebesar 0,054 $\mathrm{m}$ dengan total penurunan sebesar $0,085 \mathrm{~m}$. Dari hasil rekapitulasi penurunan pada Tabel 6 sehingga dapat disimpulkan bahwa dari besarnya beban 
(Paksial), penurunan yang terjadi pada tiap titik pembebanan masih memenuhi persyaratan yang diijinkan.

Tabel 6 Perhitungan Penurunan

\begin{tabular}{|c|c|c|c|c|c|c|c|}
\hline $\begin{array}{l}\text { Kode Titik } \\
\text { Pembebanan }\end{array}$ & $\begin{array}{l}P_{\text {ult }} \\
\text { (ton) }\end{array}$ & $\begin{array}{l}\text { Tipe pile } \\
\text { cap }\end{array}$ & $\mathrm{Si}(\mathrm{m})$ & $\mathrm{Sc}(\mathrm{m})$ & $\mathrm{S}$ total $(\mathrm{m})$ & USSR & $\mathrm{S}$ total $<\mathrm{USSR}$ \\
\hline 1 & $\begin{array}{l}5.78 \\
\end{array}$ & 2 & 0.020 & 0.033 & 0.053 & & Oke \\
\hline 2 & 9.08 & 3 & 0.022 & 0.034 & 0.056 & & Oke \\
\hline 3 & 1.39 & 2 & 0.005 & 0.008 & 0.013 & & Oke \\
\hline 4 & 8.19 & 3 & 0.020 & 0.031 & 0.051 & & Oke \\
\hline 5 & 9.34 & 3 & 0.023 & 0.035 & 0.058 & & Oke \\
\hline 6 & 3.59 & 2 & 0.012 & 0.021 & 0.033 & & Oke \\
\hline 7 & 7.24 & 2 & 0.025 & 0.041 & 0.066 & & Oke \\
\hline 8 & 3.81 & 2 & 0.013 & 0.022 & 0.035 & & Oke \\
\hline 9 & 4.91 & 2 & 0.013 & 0.017 & 0.030 & & Oke \\
\hline 10 & 7.07 & 2 & 0.024 & 0.040 & 0.064 & & Oke \\
\hline 11 & 8.60 & 3 & 0.021 & 0.032 & 0.053 & & Oke \\
\hline 12 & 9.15 & 3 & 0.022 & 0.035 & 0.057 & & Oke \\
\hline 13 & 11.90 & 4 & 0.025 & 0.042 & 0.067 & & Oke \\
\hline 14 & 14.83 & 5 & 0.025 & 0.044 & 0.069 & $15 \mathrm{~cm}$ & Oke \\
\hline 15 & 7.07 & 2 & 0.024 & 0.040 & 0.064 & & Oke \\
\hline 16 & 20.99 & 7 & 0.031 & 0.054 & 0.085 & & Oke \\
\hline 17 & 12.41 & 4 & 0.026 & 0.044 & 0.070 & & Oke \\
\hline 18 & 4.10 & 2 & 0.014 & 0.024 & 0.037 & & Oke \\
\hline 19 & 17.63 & 6 & 0.029 & 0.049 & 0.078 & & Oke \\
\hline 20 & 14.21 & 5 & 0.024 & 0.042 & 0.066 & & Oke \\
\hline 21 & 4.87 & 3 & 0.012 & 0.019 & 0.030 & & Oke \\
\hline 22 & 10.62 & 3 & 0.026 & 0.040 & 0.066 & & Oke \\
\hline 23 & 4.78 & 2 & 0.016 & 0.027 & 0.044 & & Oke \\
\hline 24 & 2.64 & 2 & 0.009 & 0.015 & 0.024 & & Oke \\
\hline 25 & 10.34 & 3 & 0.025 & 0.039 & 0.064 & & Oke \\
\hline 26 & 8.82 & 3 & 0.022 & 0.033 & 0.055 & & Oke \\
\hline 27 & 3.81 & 2 & 0.013 & 0.022 & 0.035 & & Oke \\
\hline
\end{tabular}

\section{Kesimpulan}

Berdasarkan hasil penelitian dapat diperoleh kesimpulan sebagai berikut:

1. Berdasarkan daya dukung tiang tunggal yang digunakan yaitu metode Meyerhoff diameter $40 \mathrm{~cm}$ pada kedalaman 7-meter dengan Qall $=4,06$ ton. Dari nilai daya dukung tersebut sehingga dapat diperoleh besarnya daya dukung tiang kelompok dengan kondisi 7 tiang yang dapat menahan beban sebesar 20,99 ton dimana Qg > Paksial (23,25 ton > 20,99 ton).

2. Penurunan yang terjadi akibat beban pada tiap titik pembebanan berkisar antara $1,3 \mathrm{~cm}$ sampai $8,5 \mathrm{~cm}$. Dari nilai penurunan yang diperoleh masih memenuhi batasan penurunan < $15 \mathrm{~cm}$ berdasarkan USSR.

3. Pada perencanaan pondasi strauss pile untuk rumah tinggal 2 lantai selanjutnya dilakukan analisis perbandingan biaya dan metode pelaksanaan berdasarkan jenis tanah dasar. 


\section{Referensi}

[1] Nima Esmaeilpour Shirvani, Abbasali Taghavi Ghalesari, Mohammadreza Khaleghnejad Tabari, and A. J. Choobbasti, "Improvement of the engineering behavior of sand-clay mixtures using kenaf fiber reinforcement," Transp. Geotech., vol. 19, pp. 1-8, Jan. 2019, doi: 10.1016/j.trgeo.2019.01.004.

[2] Haniffan Daruquthni Baihaqi, Yudhi Lastiasih, and Putu Tantri Kumalasari, "Zonafikasi Parameter Pemampatan Tanah Lunak Dan Analisanya Terhadap Waktu Dan Jarak Pemasangan PVD Di Wilayah Surabaya Timur."

[3] P.P. Rahardjo, Penyelidikan Geoteknik dengan Uji In-situ. GEC UK-Parahyangan, 2008.

[4] Isnaniati, "PENGARUH PENGGUNAAN TIANG BOR DAN TIANG PANCANG TERHADAP BESARNYA PENURUNAN KONSOLIDASI PADA TANAH LEMPUNG," presented at the Seminar Nasional III Teknik Sipil 2013, Universitas Muhammadiyah Surakarta, 2013.

[5] Abdul Haris HA, "STUDI PERBANDINGAN PONDASI BATU KALI, PONDASI STRAUSS DAN PONDASI PLAT SETEMPAT RUMAH TINGGAL 2 LANTAI TIPE 85/72 DILIHAT DARI BIAYA, WAKTU, DAN METODE PELAKSANAAN," in Seminar Nasional Sains dan Teknologi Terapan, Institut Teknologi Adhi Tama Surabaya, pp. 713-726.

[6] Agata Iwan Candra, "ANALISIS DAYA DUKUNG PONDASI STRAUSS PILE PADA PEMBANGUNAN GEDUNG MINI HOSPITAL UNIVERSITAS KADIRI," UkaRsT, vol. 1, no. 1, pp. 27-39, 2017.

[7] Rolf Katzenbach, Steffen Leppla, Hendrik Ramm, Matthias Seip, and Heiko Kuttig, "Design and Construction of Deep Foundation Systems and Retaining Structures in Urban Areas in Difficult Soil and Groundwater Conditions," in Procedia Engineering, 2013, vol. 57, pp. 540-548. doi: 10.1016/j.proeng.2013.04.069.

[8] Mohsen Amirmojahedi and Murad Abu-Farsakh, "Evaluation of Direct Pile-CPT Methods for Estimating the Ultimate Capacity of Driven Piles," presented at the Geo-Congress 2019: Eighth International Conference on Case Histories in Geotechnical Engineering, Mar. 2019.

[9] Tri Mulyono, Sittati Musalamah, and Nurul Hanifah, "AKTUALISASI KAPASITAS DAYA DUKUNG AKSIAL PONDASI TIANG PANCANG BERDASARKAN PARAMETER TANAH DAN STATIC LOADING TEST KASUS: PERENCANAAN GEDUNG DEWI SARTIKA DI UNJ," J. Kaji. Tek. Sipil, vol. 3, no. 1, Oct. 2018.

[10] G.G. Meyerhof, "The Ultimate Bearing Capacity of Foundations," Geotechnique, vol. 2, pp. 301332.

[11]Joseph E. Bowles, Foundation Analysis and Design. McGraw Hill International Book Company, 1988.

[12] Hary Christady Hardiyatmo, Analisis dan Perancangan Fondasi 2, 1st ed. Yogyakarta: Gadjah Mada Press, 2015.

[13]B. G. Look, Handbook of Geotechnical Investigation and Design Tables. London: Taylor and Franci, 2007.

[14]Joseph E. Bowles, ANALISIS DAN DESAIN PONDASI JILID 2. Jakarta: Erlangga, 1997. 